\title{
Elastic modulus and stress-strain curve analysis of a tungsten mine waste alkali-activated concrete
}

\author{
Pedro Silva Humbert* ${ }^{\prime}$, João Paulo de Castro Gomes ${ }^{I}$, Luis Filipe Almeida Bernardo ${ }^{I}$, Clemente Martins Pinto ${ }^{I}$, Natalia \\ Paszek ${ }^{2}$ \\ ${ }^{1}$ CMADE UBI, Centre of Materials and Building Technologies, Department of Civil Engineering and Architecture, University of Beira \\ Interior, 6200 Covilhã, Portugal \\ ${ }^{2}$ Silesian University of Technology, Faculty of Civil Engineering, Department of Structural Engineering, Akademicka 5, 44-100 Gliwice
}

\begin{abstract}
In the paper the compressive strength, the elastic modulus and the stress-strain curve of an alkaliactivated concrete were studied. A tungsten mine waste mud (TMWM), aggregate (also from the tungsten mine), glass waste and metakaolin were used as raw materials. Sodium silicate and sodium hydroxide were used as activators. First, TMWM chemical composition was determined by scanning electron microscopyenergy dispersive spectroscopy (SEM-EDS). The maximum particle size was $18 \mathrm{~mm}$. Two cubes with side dimension of $15 \mathrm{~cm}$ were prepared from the mixture. Samples were cured at $60 \mathrm{oC}$ for 24 hours. A concrete mixer, vibration table and an oven were used in the process. After the curing process, cubes were cut into seven prisms and one cube with the dimensions $15 \times 7.4 \times 7.4 \mathrm{~cm}$ and $7.4 \mathrm{~cm}$ respectively. After 28 days, the laboratory tests were performed. During the compressive strength tests, the displacements were also recorded which allowed drawing the stress-strain curve of the samples. The compressive strength ranged from 17.27 to $28.84 \mathrm{MPa}$. The elastic modulus was calculated by four different standards: ASTM, LNEC and European standard. The elastic modulus ranged from 2.48 to $7.49 \mathrm{GPa}$ what showed that the material is more elastic than ordinary Portland cement concrete.
\end{abstract}

\section{Introduction}

Global warming has exceeded its limits in 2015, therefore it is compulsory to find efficient methods for reducing greenhouse gases (GHG). The temperature anomaly was recorded also due to a high content of carbon dioxide $(\mathrm{CO} 2)$ in the atmosphere (1). The waste generation from European economic activity and households was 2.5 billion tons in 2012. The steel industry and coal combustion also produces large amount of wastes, which are often dumped in landfills resulting in potential soil and water contamination. Similarly, mining and quarrying activities can cause significant environmental, economic and social impacts (2). Researchers already showed that most of mining, quarrying and other industrial wastes can be reused in earthworks and construction as the coarser fractions in asphalt, pavements and concrete. Wastes can even become raw material for industrial applications such as marble and polyester mortar industry (3-7). Other research studies have been focused on developing a way of utilisation of the mining coarse wastes as a new polymer-based construction material in technical-artistic applications (8). The reuse of fine particles from mud tailings in the form of precursor materials in alkaliactivated binders have been considered very promising also from a technical, environmental and economic point of view (9-13).

Compressive strength is the most important mechanical property of the hardened concrete. Besides its own importance, other mechanical properties are related to the compressive strength. It is influenced by some factors such as: the characteristics and properties of the precursors; manufacturing procedures, curing conditions and the raw materials ratios (14). AABs generally can obtain high compressive strength however, the results can differ depending on the chemical composition of the used materials. Changes in the chemical composition can influence compressive strength at the different stages of the curing period (15). The modulus of elasticity of concrete is an important parameter in structural analysis which helps to determine the strain distributions and displacements of the structure (16). It is possible to estimate the modulus of elasticity of concrete by using

\footnotetext{
Corresponding author: pedro.humbert@ubi.pt
} 
expressions given in codes of practice. It can also be calculated for an existing structure using theoretical relationships between the values obtained from nondestructive testing methods and elastic modulus. These methods can be, for instance, the ultrasonic pulse velocity, wave reflection and impact echo $(17,18)$. The elastic modulus is influenced by many factors such as the volume content of aggregates, type of coarse aggregate and waterto-cement ratio. Above-mentioned factors can increase or decrease the elastic modulus depending on the concrete mixture (18).

\section{Experimental work}

This experimental program aim to investigate the compressive strength, elastic modulus and the stressstrain curve of alkali-activated concretes (AAC). The stress-strain curve was drawn using a compressive strength machine, compressiometers, load cell and data logger. The elastic modulus was calculated with the equations from three different standards, ASTM C 469 02, LNEC E 397 - 1993 and the European standard EN 12390-13.

\subsection{Materials}

Tungsten mine waste mud (TMWM) and tungsten mine waste aggregates (TMWA) were collected at the Panasqueira Mines located in the central region of Portugal. The TMWM was first dried for 24 hours in an oven at $60 \mathrm{oC}$, then it was milled and sieved using only the TMWM under $500 \mu \mathrm{m}$ as a precursor. The TMWM was submitted to a density test which showed a result of $3.0319 \mathrm{~g} / \mathrm{cm}^{3}$ and to a Blaine test that found the Blaine number of $3339 \mathrm{~cm}^{2} / \mathrm{g}$. Its chemical composition was determined by the energy dispersive spectroscopy (EDS) analyses. Which evidenced that the mud is rich in silicon dioxide (SiO2), aluminium oxide (A12O3) and iron(III) oxide (Fe2O3). Chemical composition, density and Blaine number is shown in Table 1.

Table 1. Precursors characterisation.

Compounds (\%)/properties

\begin{tabular}{lr}
\hline $\mathrm{A} 12 \mathrm{O} 3$ & 17.05 \\
$\mathrm{SiO} 2$ & 46.67 \\
$\mathrm{SO} 3$ & 7.90 \\
$\mathrm{~K} 2 \mathrm{O}$ & 4.90 \\
$\mathrm{CaO}$ & 0.69 \\
$\mathrm{FeO} 3$ & 15.47 \\
$\mathrm{MgO}$ & 4.83 \\
Density $(\mathrm{g} / \mathrm{cm} 3)$ & 3.032 \\
Blaine number $(\mathrm{cm} 2 / \mathrm{g})$ & 3339 \\
\hline
\end{tabular}

The TMWA had its gradation done with $2 \mathrm{~kg}$ of aggregates being firstly washed to remove the fine particles, then dried at $1100 \mathrm{C}$ for 24 hours and afterwards poured into a nested column of sieves from $63 \mu \mathrm{m}$ to $16 \mathrm{~mm}$. The column of sieves was shaken by a mechanical shaker, then for each sieve, the amount of accumulated material was weighted and recorded for further calculations. The gradation is shown in Figure 1.

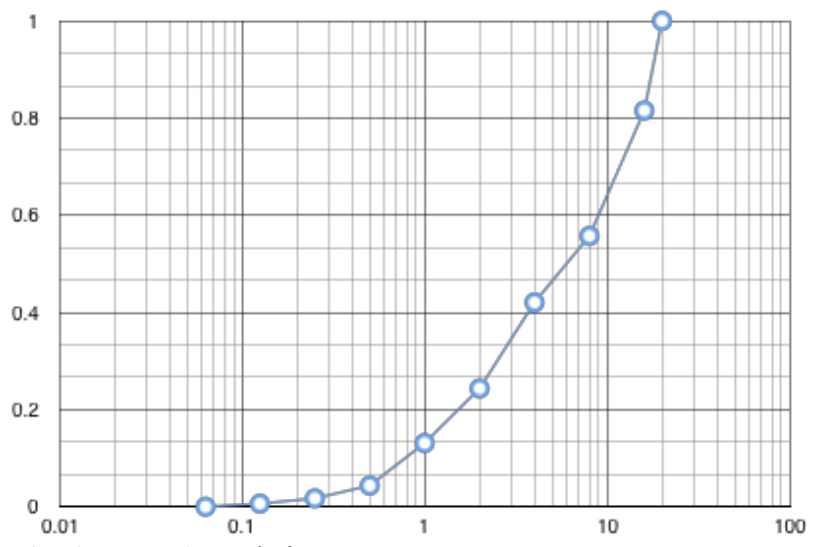

Fig. 1. TMWA gradation.

Apart from the TMWM, glass waste and metakaolin were used in the mixture. Both materials had their density, Blaine number and chemical composition determined in the same way as the TMWM. This data is also shown in Table 1.

Two different activators were used during the experiment, sodium silicate $(\mathrm{Na} 2 \mathrm{SiO} 2) \mathrm{n}$ and sodium hydroxide $\mathrm{NaOH}$.

\subsection{Samples preparation}

Two cubes with side dimension of $15 \mathrm{~cm}$ were designed. At first TMWM, glass and metakaolin were mixed until they become a homogenous powder. Then the TMWA was also poured into the concrete mixer. At the end, the activators were added. The mixture was being mixed for five minutes and then poured into the moulds. The moulds were placed on a vibration table and vibrated for two minutes. Finally, they were cured in an oven for 24 hours at $60 \mathrm{oC}$. At the $28^{\text {in }}$ day the two cubes were cut into seven prisms and one cube with the dimensions $15 \times 7.4 \times 7.4 \mathrm{~cm}$ and $7.4 \mathrm{~cm}$ respectively. Prepared samples were subjected to the tests. The mixture design is shown in Table 2.

Table 2. Mixture design.

\begin{tabular}{ccccccc} 
Mixture & \multicolumn{2}{c}{ Precursors } & \multicolumn{2}{c}{ Activators } & Aggregates \\
& $\begin{array}{c}\text { Mud } \\
\text { waste }\end{array}$ & Glass & Metakaolin & $\begin{array}{c}\text { Sodium } \\
\text { silicate }\end{array}$ & $\begin{array}{c}\text { Sodium } \\
\text { hydroxide }\end{array}$ & Panasqueira \\
\hline 1 & 4000 & 2000 & 1333 & 1744 & 750 & 19779 \\
\hline
\end{tabular}

\subsection{Test methods}

The stress-strain curve was drawn through a system which consisted of a compressive strength machine Seidner D7940 Riedlingen, two compressometers, a load cell and a data logger which recorded all the data simultaneously at each second. All samples were tested at age of 28 days. In the case of the cube sample, one compressometer was not 
able to give results, so this sample had only one stressstrain curve. The built system is shown in Figure 2.

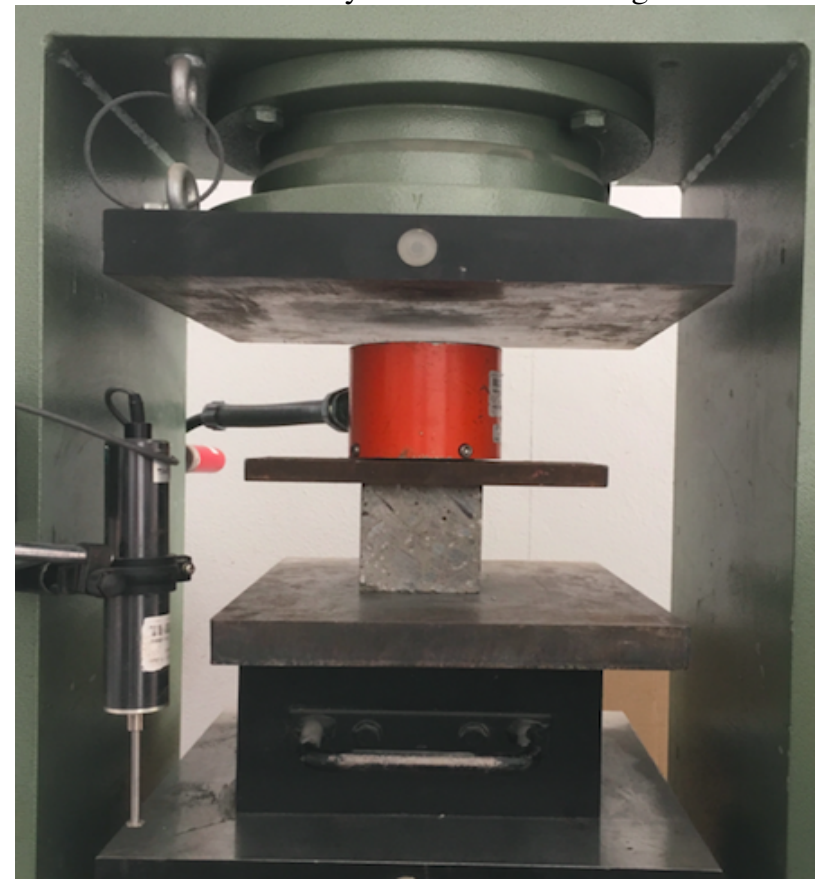

Fig. 2. System.

For the elastic modulus calculations three standards were used, ASTM C 469 - 02, LNEC E 397 - 1993 and the European standard EN 12390-13. From the stress-strain curves the compressive strength of each sample was taken. These values were used during calculating the elastic modulus per the equations from the standards. For calculations of the elastic modulus of the prisms for which displacements where measured by two compressiometers, the average result was taken.

Per the ASTM C 469, the elastic modulus is calculated by division of the difference of the stress and strain in two points. The first point is in the $40 \%$ of the ultimate load. The second point is where the displacement is equal to 50 millionths. The procedure is shown in Equation 1.

$$
E=\left(S_{2}-S_{1}\right) /\left(\varepsilon_{2}-0.00050\right)
$$

Where $\mathrm{E}$ is the modulus of elasticity, $\mathrm{S}_{2}$ is stress corresponding to the $40 \%$ of the ultimate load, $S$ is stress corresponding to a longitudinal strain $\varepsilon_{1}$ and $\varepsilon_{2}$ is the longitudinal strain produced by stress $\mathrm{S}_{2}(19)$.

In the European Standard, modulus of elasticity is calculated by similar relationship. There are two different equations with the same upper stress, corresponding to the one third of the ultimate load, and two different lower stresses. The first one should be between ten and fifteen percent of the compressive strength. The second stress should be lower than the first stress and higher then 0.5 $\mathrm{MPa}$. Equations 2 and 3 show the calculation procedure.

$$
\begin{aligned}
& E=\Delta \sigma / \Delta \varepsilon=\left(\sigma_{a^{m}}-\sigma_{b^{\prime \prime}}\right) /\left(\varepsilon_{\mathrm{a}}-\varepsilon_{\mathrm{p}}\right) \\
& E=\Delta \sigma / \Delta \varepsilon=\left(\sigma_{a^{m}}-\sigma_{p^{m}}\right) /\left(\varepsilon_{\mathrm{a}}-\varepsilon_{\mathrm{p}}\right)
\end{aligned}
$$

Where $\mathrm{E}$ is the modulus of elasticity, $\Delta \sigma$ is the difference between the upper and lower stresses and $\Delta \varepsilon_{0}$ is respective strain difference for each stress (20).

Procedure for calculating modulus of elasticity given by LNEC is similar to the one given by European Standard, however, there is only one equation and the lower stress is between 0.5 and 1.0 MPa as shown in Equation 4 (21)

$$
E=\Delta \sigma / \Delta \varepsilon=\left(\sigma_{a}-\sigma_{b}\right) /\left(\varepsilon_{a}-\varepsilon_{\mathrm{o}}\right)
$$

\section{Results and discussion}

The results of the compressive strength of tested samples are shown in Table 3.

Table 3. Compressive strength and elastic modulus data.

\begin{tabular}{cccccc} 
Sample & $\begin{array}{c}\text { Compressive } \\
\text { strength } \\
\text { (MPa) }\end{array}$ & ASTM & \multicolumn{4}{c}{ Elastic Modulus (GPa) } \\
$\mathrm{E}_{\mathrm{cs}}=\mathrm{E}_{\mathrm{cs}}(\mathrm{A})$ & $\mathrm{E}_{\mathrm{cs}}(\mathrm{B})$ & LNEC \\
\hline Prism 1 & 25.09 & 3.4 & 5.35 & 4.25 & 3.85 \\
Prism 2 & 23.9 & 3.95 & 4.7 & 4.23 & 3.81 \\
Prism 3 & 21.4 & 2.82 & 3.86 & 3.51 & 3.23 \\
Prism 4 & 17.27 & 3.24 & 3.87 & 3.27 & 3.38 \\
Prism 5 & 26.52 & 1.2 & 7.96 & 7.07 & 6.52 \\
Prism 6 & 19.09 & 1.65 & 5.15 & 5.14 & 4.6 \\
Prism 7 & 22.71 & 5.65 & 6.07 & 5.77 & 4.69 \\
Average & 22.28 & 3.13 & 5.28 & 4.75 & 4.30 \\
\hline
\end{tabular}

Due to the influence of casting, compacting, demoulding, cutting and the inconstant load rate during test, there are some differences between results. The highest value of compressive strength achieved cubic sample (28.84 MPa) however, as it has different dimensions it could not be compared with the prismatic samples. The compressive strength results of tested prisms ranged from 17.27 $\mathrm{MPa}$ to $26.52 \mathrm{MPa}$. The average value of obtained results was 22.28 MPa. Compressive strength of tested AAC can be compared to compressive strength of concrete C20/25 (22) which is $25 \mathrm{MPa}$ for cubic samples and $20 \mathrm{MPa}$ for cylindrical samples. Taking into consideration the compressive strength, AAC based on TMWM and containing TMWA evidence a potential to be used on structural applications.

Obtained results can be compared with similar test carried on alkali-activated material (AAM) based on tungsten mine waste mud with no addition of coarse aggregate (23). In mentioned paper, there were tested two types of samples: small cubic samples of dimensions $4 \times 4 \times 4 \mathrm{~cm}$ and cylindrical samples of height $12 \mathrm{~cm}$ and diameter $5.9 \mathrm{~cm}$. The average compressive strength of tested cubic samples was equal to $26.28 \mathrm{MPa}$. This value is slightly higher than results showed in Table 3 however, smaller size concrete samples can obtain grater compressive strengths than bigger samples due to the scale effect. Average 
compressive strength of tested cylinders was $16.80 \mathrm{MPa}$. This value is lower than average compressive strength obtained in current research although, the ratio of side dimensions of samples was similar in both papers. The reason why AAM of similar composition (23) obtained lower compressive strength can be the lack of coarse aggregate. As it was shown by series of laboratory tests, bigger compressive strengths are obtained by AAM samples containing coarse aggregate independently on aggregate type (24).

Because of divergences in results once the standard deviation is equal to 3.04 , successive researches should be carried on to confirm good compressive strength of tested material. Better compaction of the fresh mixture can even increase the achieved strength.

The other goal of presented paper was to calculate elastic modulus of tested AAC. Because of lack of standards concerning AACs, elastic modulus was calculated based on concrete standards. Table 3 shows the elastic modulus values calculated for each sample and each standard. The elastic modulus ranged from 1.20 to $7.96 \mathrm{GPa}$ which characterise this AAC as flexible material. The average elastic modulus calculated per ASTM is $3.13 \mathrm{GPa}$; regarding the European Standard 5.28 GPa and 4.75 GPa; and $4.30 \mathrm{GPa}$ based on LNEC. The average of all results is equal to $4.36 \mathrm{GPa}$. Upon analysis of presented results, it can be observed that AAC containing TMWM and TMWA has much lower modulus of elasticity than ordinary Portland cement concrete. ACI 318-89 standard (25) says that a concrete with a compressive strength of 22.28 MPa has an elastic modulus of $22.30 \mathrm{GPa}$ which is five times bigger than ACC elastic modulus. Lower elastic modulus indicates that AAC is more elastic than ordinary Portland cement concrete. Current work shows similar results when compared with a different research (23), which has an average elastic modulus of $3.79 \mathrm{GPa}$ for ACC cylinders.

The stress strain curves supported the elastic modulus calculation and can be seen at Figure 3.

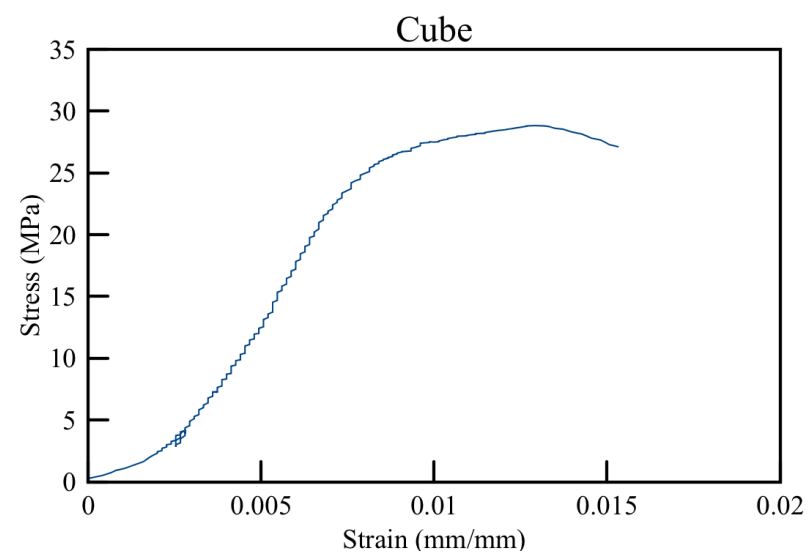

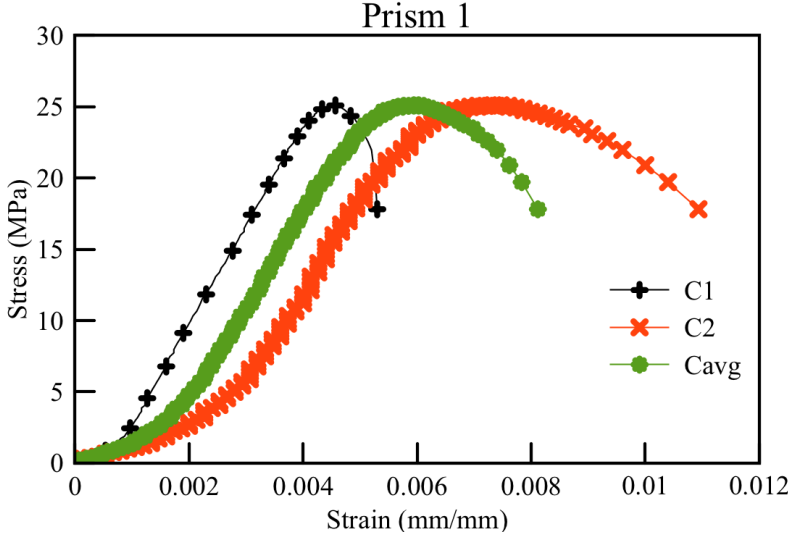

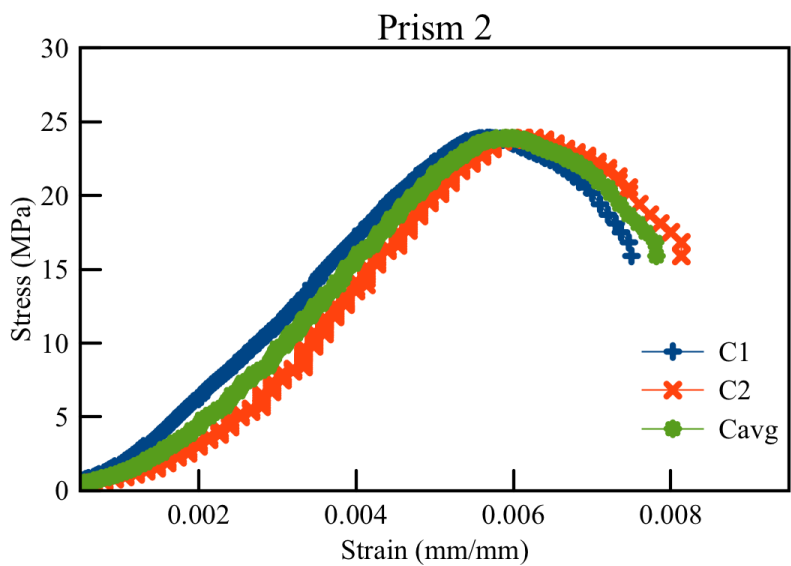

Prism 3
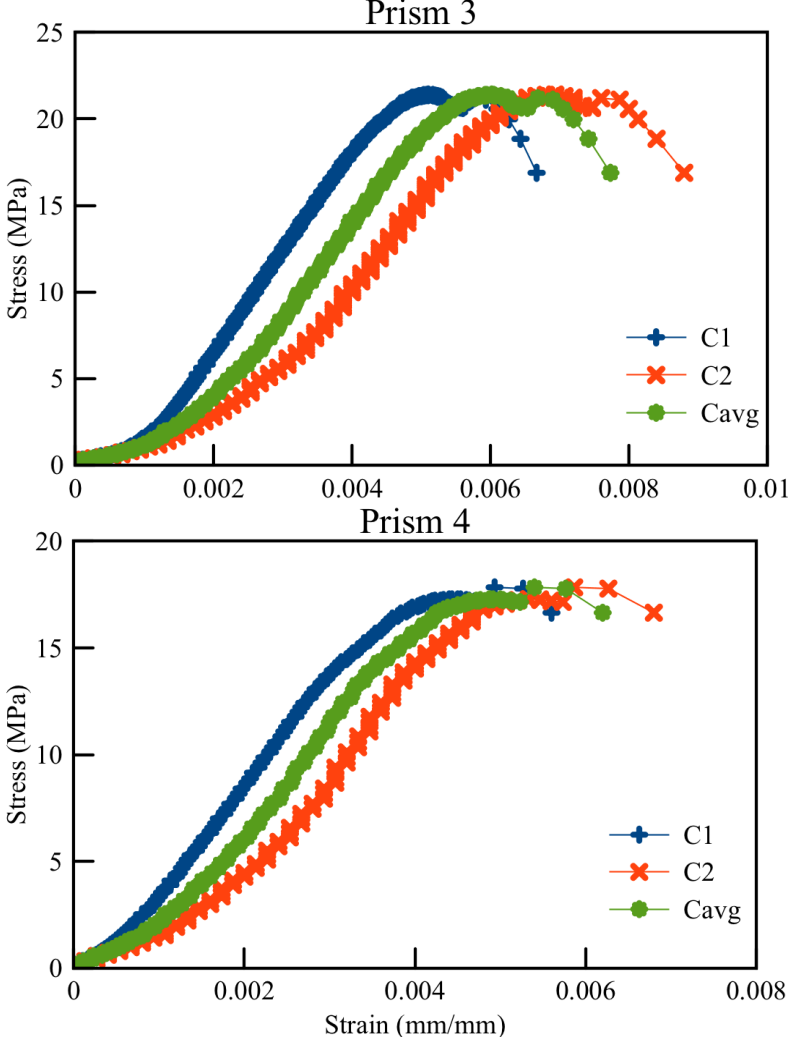

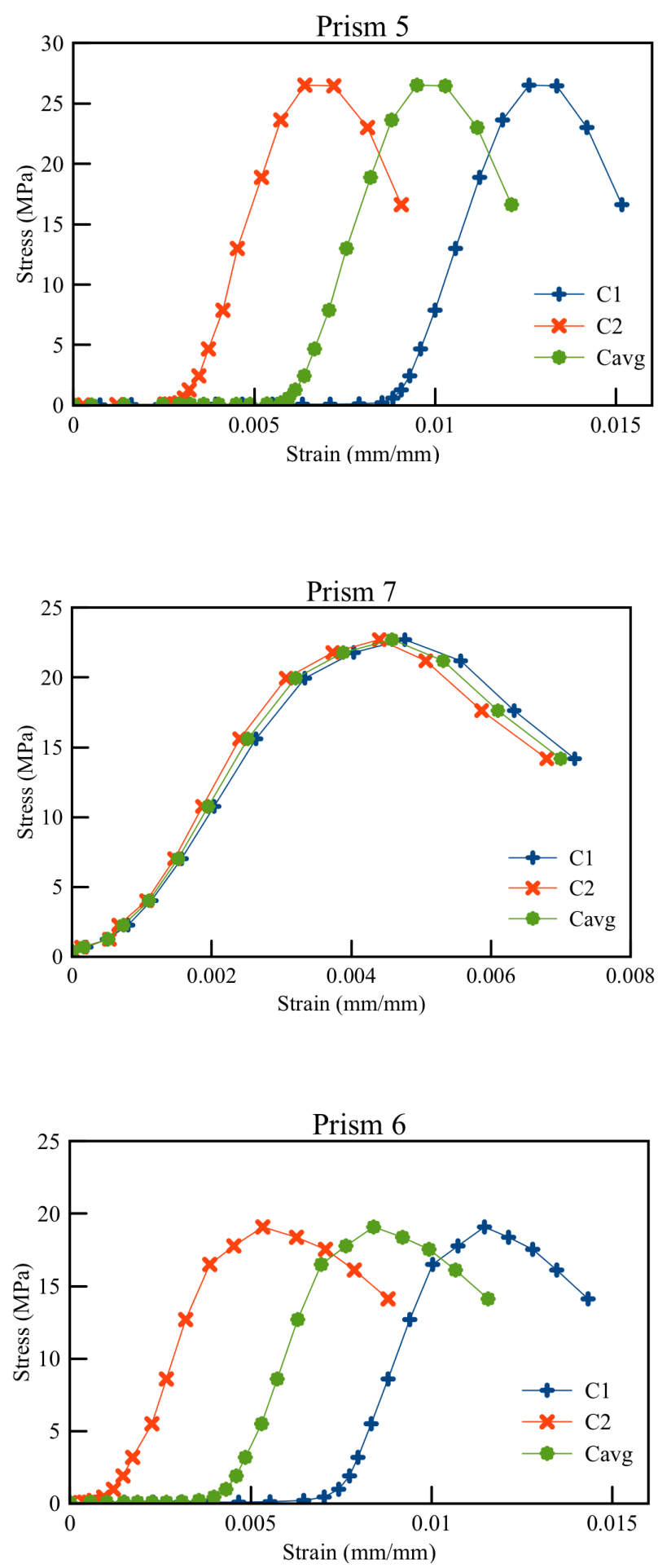

Fig. 3. Stress-strain curves.

\section{Conclusion}

After doing this experimental work it was possible to understand that ACC is a flexible material when compared with ordinary Portland cement concrete with a five times lower elastic modulus than the traditional construction material.

\section{Acknowledgement}

This study was funded by the European Commission Horizon 2020 MARIE Skłodowska-CURIE Research and Innovation Staff Exchange Scheme (Grant Agreement Number 645696).

\section{References}

1. Szulejko JE, Kumar P, Deep A, Kim KH. Global warming projections to 2100 using simple $\mathrm{CO} 2$ greenhouse gas modeling and comments on $\mathrm{CO} 2$ climate sensitivity factor. Atmos Pollut Res [Internet]. 2016;1-5. Available from: http://dx.doi.org/10.1016/j.apr.2016.08.002

2. Eurostat. Waste statistics Main statistical findings -Total waste generation. 2016;(September 2015):3.

3. Castro-Gomes J, Albuquerque A, Silva AP, Cano RP, Suarez JD. Valorização de resíduos de minas em compósitos poliméricos. Mater Construção. 2011;2006(March 2006):40-6.

4. Hebhoub H, Aoun H, Belachia M, Houari H, Ghorbel E. Use of waste marble aggregates in concrete. Constr Build Mater. 2011;25(3):116771 .

5. Mun KJ, Choi NW, So SY, Soh YS. Influence of fine tailings on polyester mortar properties. Constr Build Mater. 2007;21(6):1335-41.

6. Raupp-Pereira F, Ball RJ, Rocha J, Labrincha JA, Allen GC. New waste based clinkers: Belite and lime formulations. Cem Concr Res. 2008;38(4):511-21.

7. Yellishetty M, Karpe V, Reddy EH, Subhash KN, Ranjith PG. Reuse of iron ore mineral wastes in civil engineering constructions: A case study. Resour Conserv Recycl. 2008;52(11):1283-9.

8. Castro-Gomes JP, Silva AP, Cano RP, Durán Suarez J, Albuquerque A. Potential for reuse of tungsten mining waste-rock in technical-artistic value added products. J Clean Prod [Internet]. 2012;25:34-41. Available from: http://dx .doi.org/10.1016/j.jclepro.2011.11.064

9. Kumar A, Kumar S. Development of paving blocks from synergistic use of red mud and fly ash using geopolymerization. Constr Build Mater [Internet]. 2013;38:865-71. Available from:

http://dx.doi.org/10.1016/j.conbuildmat.2012.09. 013

10. Okada K, Ooyama A, Isobe T, Kameshima Y, Nakajima A, MacKenzie KJD. Water retention properties of porous geopolymers for use in cooling applications. J Eur Ceram Soc. 2009;29(10):1917-23.

11. Pacheco-Torgal F, Jalali S, Castro Gomes JP. Geopolymers structure, processing, properties and industrial applications. In: Geopolymers Structure, processing, properties and industrial applications. 2009. p. 267-93.

12. Silva I, Castro-Gomes JP, Albuquerque A. Effect 
of immersion in water partially alkali-activated materials obtained of tungsten mine waste mud. Constr Build Mater [Internet]. 2012;35:117-24. Available from: http://dx.doi.org/10.1016/j.conbuildmat.2012.02. 069

13. Zhang L, Ahmari S, Zhang J. Synthesis and characterization of fly ash modified mine tailings-based geopolymers. Constr Build Mater [Internet]. 2011;25(9):3773-81. Available from: http://dx.doi.org/10.1016/j.conbuildmat.2011.04. 005

14. Ding Y, Dai JG, Shi CJ. Mechanical properties of alkali-activated concrete: A state-of-the-art review. Constr Build Mater [Internet]. 2016;127:68-79. Available from: http://dx.doi.org/10.1016/j.conbuildmat.2016.09. 121

15. Kramar S, Šajna A, Ducman V. Assessment of alkali activated mortars based on different precursors with regard to their suitability for concrete repair. Constr Build Mater [Internet]. 2016;124:937-44. Available from: http://linkinghub.elsevier.com/retrieve/pii/S0950 061816312818

16. Topcu IB. Alternative estimation of the modulus of elasticity for dam concrete. Cem Concr Res. 2005;35(11):2199-202.

17. Yildirim H, Sengul O. Modulus of elasticity of substandard and normal concretes. Constr Build Mater. 2011;25(4):1645-52.

18. Zhou Y, Gao J, Sun Z, Qu W. A fundamental study on compressive strength, static and dynamic elastic moduli of young concrete. Constr Build Mater [Internet]. 2015;98:137-45. Available from: http://dx.doi.org/10.1016/j.conbuildmat.2015.08. 110

19. American Society for Testing Material. ASTM C 469 - 02: Standard Test Method for Static Modulus of Elasticity and Poisson's Ratio of Concrete. West Conshohocken, Pennsylvania, USA; 2002. 1-5 p.

20. EUROPEAN COMMITTEE FOR STANDARDIZATION. EN 12390-13: Testing hardened concrete - Part 13: Determination of secant modulus of elasticity in compression Essai. Brussels; 2013.

21. LNEC LN de EC. E 397-1993 Ec: Determinacao do Modulo de Elasticidade em Compressao. Vol. 3. Lisboa; 1993. 1-2 p.

22. Standard B. Eurocode 2 : Design of concrete structures. Concrete. 2003;(July).

23. Górski M, Krzywoń R, Safuta M, Paszek N, Dawczyński S, Pizoń J. Badania cech materiałowych geopolimerów z odpadowych kruszyw pokopalnianych i ich symulacje numeryczne. Mater Bud [Internet]. 2016 Aug 5 [cited 2017 Jul 28];1(8):91-3. Available from: http://sigma-not.pl/publikacja-100246-20168.html
24. Pacheco-Torgal F, Castro-Gomes JP, Jalali S. Investigations of tungsten mine waste geopolymeric binder: Strength and microstructure. Constr Build Mater. 2008;22(11):2212-9.

25. ACI ACI. Building code requirements for structural concrete (ACI 318-95). Farmington Hills; 1995. 